\title{
Relationship of stem water potential and leaf conductance to vegetative growth of young olive trees in a hedgerow orchard
}

\author{
María Gómez-del-Campo , A. Leal, and C. Pezuela \\ Dpto. Producción Vegetal: Fitotecnia, Universidad Politécnica de Madrid, 28040 Madrid, Spain. \\ Corresponding author. Email: maria.gomezdelcampo@upm.es
}

\begin{abstract}
In 2005, four irrigation treatments were applied to a 3-year-old cv. Cornicabra orchard. In T1, wetted soil volume was maintained close to field capacity by irrigating when soil sensors indicated that soil water potential in the root zone had fallen to $-0.03 \mathrm{MPa}$ and $0.06 \mathrm{MPa}$ from spring until 15 August and from 15 August until September, respectively. On those days, 8, 6, 4, and $2 \mathrm{~h}$ of irrigation was applied to T1, T2, T3, and T4, so that over the season they received 106, 81, 76 and $31 \mathrm{~mm}$ of irrigation, respectively. The high value for $\mathrm{T} 3 \mathrm{was}$ the result of a valve failure on 13 June. Measurements were maintained throughout the experimental period of relative extractable water (REW) to $1 \mathrm{~m}$ depth at the wetted volume $\left(0.30 \mathrm{~m}\right.$ from a drip emitter), shoot length, trunk diameter, stem water potential $\left(\Psi_{\text {stem }}\right)$ and leaf conductance $\left(\mathrm{g}_{1}\right)$. The irrigation treatment significantly affected REW $(P<0.10), \Psi_{\text {stem }}, \mathrm{g}_{1}$ and vegetative growth $(P<0.05) . \Psi_{\text {stem }}$, and trunk diameter were the least variable parameters and $\Psi_{\text {stem }}$ and shoot growth were the most sensitive to water stress. Although T1 received $24 \%$ more water than $\mathrm{T} 2$, no significant differences were detected in vegetative growth. T2 should be considered the optimum irrigation value. The mean monthly $\mathrm{Kc}$ for $\mathrm{T} 2$ was 0.086 . The failure of the valve in $\mathrm{T} 3$ simulated a wet spring followed by limited irrigation. Irrigation applied was similar to T2 but shoot growth stopped one month earlier and lower values of $\Psi_{\text {stem }}$ and $\mathrm{g}_{1}$ were observed after mid August. REW was highly related to vegetative growth, $66 \%$ of maximum being achieved at REW 0.53 and $50 \%$ at 0.45 . g was independant of plant or soil water status and did not determine vegetative growth. A strong relationship established $\Psi_{\text {stem }}$ as a good indicator of vegetative growth and hence of water stress. Shoot growth was $66 \%$ of maximum at $\Psi_{\text {stem }}-1.5 \mathrm{MPa}$ and $50 \%$ at $-1.8 \mathrm{MPa}$.
\end{abstract}

Additional keywords: Olea europaea L., water relations, irrigation, superintensive olive grove.

\section{Introduction}

Water will probably become less available and increasingly expensive in the Mediterranean area in the near future, restricting its use for agricultural purposes. Although olive (Olea europaea L.) has been grown for centuries under rainfed conditions due to its adaptation to water shortage (Fernández and Moreno 1999; Connor 2005), orchards are increasingly being irrigated because even small applications of water can have large benefits on oil production. Pastor et al. (1999) reported that yield was nearly doubled when $150 \mathrm{~mm}$ of irrigation was applied in a region with a mean annual rainfall of $506 \mathrm{~mm}$.

Traditional olive orchards, trained in a globe vase form, are maintained at low foliage cover to restrict water use, while as hedgerows, new orchards are designed to maximise the interception of incident solar radiation and optimise its distribution over the canopy (Connor 2006). The first hedgerow orchards, also called super-high-density (714-1975 olives/ha), were planted in Spain at the beginning of the 1990s. The objective was for high yields commencing in the early years and an orchard structure suited to mechanical harvesting. In these plantings, trees are usually pruned to a central leader and fruit are harvested with modified grape harvesters. Due to the greater interception capacity of the canopy, it is predicted that water consumption will be higher (Connor 2005).
Irrigation scheduling of field crops commonly remains based on measurements and a crop coefficient approach (Allen et al. 1998) but this method has limited application to fruit-tree orchards due to the irregular distribution of the canopy and root system. Given the variability, it is very difficult to establish universal threshold values of soil water content for irrigation. Attention turns, therefore, to plant-based measurements that should, theoretically, provide the best indicators of plant water stress and hence of irrigation requirement because they integrate the effect of soil, plant and atmospheric conditions on water availability within the plant itself (Hsiao 1990; McCutchan and Shackel 1992; Shackel et al. 1997; Jones 2004).

Among possible plant-based measurements, stem water potential $\left(\Psi_{\text {stem }}\right)$, the water potential of a non-transpiring attached leaf, has been proposed as a physiologically based water-stress indicator and a guide for irrigation practice in deciduous fruit trees (Shackel et al. 1997; Naor et al. 1999). It has also been shown to be a sensitive parameter of water status in young (Moriana and Fereres 2002) and adult olive trees (Moriana et al. 2003; Fernández et al. 2006).

The irrigation response of adult hedgerow olive orchards has been studied (Berenguer et al. 2006; Grattan et al. 2006) but there is no available information on youth orchards. Optimum irrigation management in young hedgerow orchards should seek rapid occupation of the row, without use of excess water. 
That requires the application of the minimum amount that does not restrict growth. To achieve this, an effective irrigation index able to establish threshold values for irrigation should not only be sensitive to water stress (Moriana and Fereres 2002) but should also be closely related to vegetative growth. The work reported here was conducted with four irrigation treatments to characterise the growth response of a young hedgerow olive orchard to a range of $\Psi_{\text {stem }}$ values, and the associated effect on leaf conductance, to evaluate its usefulness as a plant-based indicator for irrigation scheduling.

\section{Materials and methods}

The experiment was conducted at the Olive-Production Centre of The Comunidad de Madrid, Spain (latitude $40^{\circ} 04^{\prime} \mathrm{N} ; 03^{\circ} 31^{\prime} \mathrm{W}$; alt. $524 \mathrm{~m}$ ). The soil is a clay loam (Xerochrept Calcixerollic) with an effective rooting depth of $1 \mathrm{~m}$. A weather station at the site registered wind speed and direction, rainfall, temperature, humidity, and global radiation every $30 \mathrm{~min}$ and calculated vapour pressure deficit (VPD) and ETo by the PenmanMonteith method (Allen et al. 1998) from these climatic variables.

An area of $2500 \mathrm{~m}^{2}$ was planted in June 2003 with cv. Cornicabra at a spacing of 3.75 by $1.8 \mathrm{~m}$. Plants were trained to a central leader during the first 3 years. Irrigation was by drip emitters at $0.60-\mathrm{m}$ spacing in a single line for each row of tree and provided $2 \mathrm{~L} / \mathrm{h}$. Weeds were controlled using a non-residual herbicide and fertiliser was applied according to leaf analyses made each year in July. The experiment reported here relates to the year 2005, the third year of growth in the field. In the previous year, when the trees were smaller, treatments T1, $\mathrm{T} 2$, T3, and T4 received $56,46,36$, and $26 \mathrm{~mm}$, respectively, during the period 24 June 2004 to 15 September 2004.

On 20 May, a general irrigation of $6.2 \mathrm{~mm}$ was applied to all trees in order to wet the soil. Then on 3 June, four experimental irrigation treatments (T1-T4) were established in a completely randomised 4-block design. Each repetition consisted of 21 trees ( 5 control and 16 border). Control treatment T1 was irrigated according to the responses of 6 Watermark $^{\mathrm{TM}}$ (Irrometer, $\mathrm{Ca}$, USA) sensors located in pairs at $0.3 \mathrm{~m}$ depth and $0.3 \mathrm{~m}$ from the emitters and trunk (emitter was near the trunk) of 3 representative trees. T1 was irrigated for $8 \mathrm{~h}$ when the median value of all sensors indicated a soil water potential of $-0.03 \mathrm{MPa}$ from spring until 15 August and $0.06 \mathrm{MPa}$ from 15 August until September. Less water was applied after 15 August in order to prevent autumn frost. Previous detailed measurements at the site revealed that this reaches the wetting volume at $0.9 \mathrm{~m}$ depth, and therefore to the effective rooting depth without excessive drainage. On those days, T2, T3, and T4 were also irrigated with 75,50 and $25 \%$ of the water applied to T1, respectively. From 20 May until 7 September irrigation was required nearly every week to maintain the wetted volume of T1. The treatments were maintained until 4 September 2005 and then on 29 September, all treatments received $7 \mathrm{~mm}$ of irrigation.

The distinction between treatments was reduced when the valve controlling $\mathrm{T} 3$ failed on 13 June and that treatment received $31 \mathrm{~h}$ of irrigation. To compensate, no water was applied at the next scheduled irrigation. In consequence, over the entire irrigation period, trees in $\mathrm{T} 1, \mathrm{~T} 2, \mathrm{~T} 3$, and $\mathrm{T} 4$ received
$714,546,516$, and $210 \mathrm{~L}$, respectively, equivalent to $106,81,76$, and $31 \mathrm{~mm}$ of irrigation. In this way, T2, T3, and T4 received 76, 72 and $29 \%$ of water applied to $\mathrm{T} 1$.

Soil water content $\left(\theta, \mathrm{m}^{3} / \mathrm{m}^{3}\right)$ was measured weekly at $0.10-\mathrm{m}$ intervals to $1 \mathrm{~m}$, at least 3 days after irrigation, from 2 June to 7 October using a portable capacitance prove (Diviner 2000, Sentek Pty Ltd, Australia). One access tube of $1.5-\mathrm{m}$ length was installed in each block and treatment in the wetted soil volume at a distance of $0.30 \mathrm{~m}$ from a drip emitter and an olive trunk. Relative extractable water (REW) was calculated by the equation of Granier (1987): REW $=\left(\theta-\theta_{\min }\right) /\left(\theta_{\max }-\theta_{\min }\right)$, where $\theta(\mathrm{mm})$ is the actual soil water content, $\theta \mathrm{min}$ is the minimum soil water content measured during the experiment in each block (mean value of $202 \mathrm{~mm}$ ), and $\theta_{\max }$ is the soil water content at field capacity (mean value of $342 \mathrm{~mm}$ ).

Vegetative growth was recorded weekly by measuring shoot length and trunk diameter. Shoot length was measured on 3 trees of each replicate from 2 June to 29 September and trunk diameter on the same trees from 2 June to 6 October. Earlier, during winter (17 March), trunk diameter had been measured at $0.30-\mathrm{m}$ height in the control trees. Tree heights were measured at the beginning and end of the experimental sequence. On 16 June flowers were removed from control trees to reduce variability in growth due to the highly irregular flowering in these young trees.

The effect of irrigation treatment was measured as stem water potential and leaf conductance in one tip or leaf per tree of 4 trees per treatment in one block. Stem water potential $\left(\Psi_{\text {stem }}, \mathrm{MPa}\right)$ was measured at solar noon in 4 tips of shoots in the shaded side of the row near the trunk previously covered for $1 \mathrm{~h}$ with aluminium foil (McCutchan and Shackel 1992) to allow the water potential of the leaf to equilibrate with the water potential of the stem (Begg and Turner 1970), using a pressure chamber (Soil Moisture Equip., Santa Barbara, CA, USA). Leaf conductance $\left(\mathrm{g}_{1}\right)$ was measured at the same time on 4 healthy leaves exposed to the sun, using a steady-state porometer (Li-1600, Li-Cor, Lincoln, NE, USA). Until 14 July, the measured leaves had been formed during 2004, but subsequently, new, current-season leaves were selected for measurement. Measurements of soil moisture, vegetative growth, $\Psi_{\text {stem }}$ and $g_{1}$ were made on the same days.

Relationships between vegetative growth and REW, $\mathrm{g}_{1}$ and $\Psi_{\text {stem }}$ during the shoot growing period (2 June-25 August) were studied.

Data were subjected to analysis of variance using MSTAT-C (University of Michigan, USA). Before analysis, REW data were transformed by arc-sin square-root to a normal distribution. Least significant differences $(P<0.05$ and $P<0.10)$ were used to separate treatment means using Duncan's multiple range test. Regression analysis was performed to determine the relationship between parameters.

\section{Results \\ Environmental conditions and tree development}

The weather data for the site are summarised in Table 1. During the experimental period, the highest temperature was recorded on 7 August $\left(40.1^{\circ} \mathrm{C}\right)$ and the lowest on 28 January $\left(-12.7^{\circ} \mathrm{C}\right)$. July was the hottest month with a mean temperature of $26.5^{\circ} \mathrm{C}$. January was the month with the lowest solar radiation 
measurement $\left(6.2 \mathrm{MJ} / \mathrm{m}^{2}\right)$ and July the highest $\left(38.6 \mathrm{MJ} / \mathrm{m}^{2}\right)$. Evaporative conditions remained strong throughout the experimental year, with a cumulative ETo of $1409 \mathrm{~mm}$ from November 2004 until October 2005 and $778 \mathrm{~mm}$ from June to September. On a daily basis, the highest values for the experimental period occurred in July (average $7.4 \mathrm{~mm}$ ) and the lowest (average $4.6 \mathrm{~mm}$ ) in September. The experimental period was one of very low rainfall with less than half of the mean, comprising $193 \mathrm{~mm}$ from November 2004 until October 2005 and $30 \mathrm{~mm}$ from June to September 2005.

Table 2 presents weather conditions on the days when measurements were made of stem water potential and leaf conductance. The highest temperature occurred at the beginning of July $\left(30.4^{\circ} \mathrm{C}\right)$ and the end of August $\left(29.4^{\circ} \mathrm{C}\right)$, both days with very low humidity and high evaporation (10.7 and $8.7 \mathrm{~mm}$, respectively) and high values of VPD at solar noon (4.58

Table 1. Mean monthly relative humidity (HR) and radiation, absolute minimum $\left(\mathbf{T}_{\min }\right)$ and maximum $\left(\mathbf{T}_{\max }\right)$ temperature, accumulated rainfall and ETo from October 2004 to December 2005

\begin{tabular}{lccrrrr}
\hline & $\begin{array}{r}\mathrm{HR} \\
(\%)\end{array}$ & $\begin{array}{r}\text { Radiation } \\
\left(\mathrm{MJ} / \mathrm{m}^{2}\right)\end{array}$ & $\begin{array}{r}\mathrm{T}_{\min } \\
\left({ }^{\circ} \mathrm{C}\right)\end{array}$ & $\begin{array}{r}\mathrm{T}_{\max } \\
\left({ }^{\circ} \mathrm{C}\right)\end{array}$ & $\begin{array}{c}\text { Rain } \\
(\mathrm{mm})\end{array}$ & $\begin{array}{r}\text { ETo } \\
(\mathrm{mm})\end{array}$ \\
\hline Oct. 04 & 71.3 & 11.4 & 1.9 & 31.4 & 83.6 & 84.8 \\
Nov. 04 & 83.4 & 8.9 & -3.8 & 19.9 & 20.8 & 46.7 \\
Dec. 04 & 85.4 & 6.2 & -5.7 & 16.9 & 19.8 & 31.8 \\
Jan. 05 & 72.6 & 8.9 & -12.7 & 17.1 & 2.8 & 36.5 \\
Feb. 05 & 70.3 & 11.8 & -9.2 & 19.1 & 10.2 & 49.2 \\
Mar. 05 & 64.9 & 15.8 & -8.2 & 23.6 & 13.2 & 84.5 \\
Apr. 05 & 58.9 & 22.9 & -4.7 & 30.9 & 5.0 & 122.7 \\
May 05 & 48.2 & 26.1 & 2.1 & 35.2 & 14.2 & 175.1 \\
June 05 & 38.1 & 37.4 & 10.6 & 38.3 & 15.8 & 205.9 \\
July 05 & 31.2 & 38.6 & 10.2 & 39.2 & 4.2 & 229.3 \\
Aug. 05 & 33.6 & 32.9 & 8.0 & 40.1 & 0.0 & 204.7 \\
Sep. 05 & 42.9 & 27.1 & 2.4 & 36.0 & 10.0 & 138.4 \\
Oct. 05 & 61.4 & 17.9 & 1.5 & 31.5 & 77.3 & 84.8 \\
Nov. 05 & 79.0 & 11.1 & -4.1 & 21.0 & 37.7 & 34.9 \\
Dec. 05 & 79.8 & 10.3 & -6.4 & 15.4 & 15.3 & 36.2 \\
\hline
\end{tabular}

Table 2. Daily ETo, average temperature $\left(T_{\text {med }}\right)$, and relative humidity (RH) and vapour pressure deficit at solar noon (VPD 12:00) on the days of leaf transpiration and stem water potential measurements

\begin{tabular}{lcccc}
\hline & $\begin{array}{c}\text { ETo } \\
(\mathrm{mm} / \text { day })\end{array}$ & $\begin{array}{c}\mathrm{T}_{\text {med }} \\
\left({ }^{\circ} \mathrm{C}\right)\end{array}$ & $\begin{array}{c}\text { RH } \\
(\%)\end{array}$ & $\begin{array}{c}\text { VPD 12:00 } \\
(\mathrm{kPa})\end{array}$ \\
\hline 26 May & 7.7 & 25.7 & 25.8 & 3.57 \\
09 June & 8.5 & 25.0 & 32.4 & 3.13 \\
17 June & 9.5 & 28.6 & 29.1 & 3.59 \\
30 June & 9.4 & 23.3 & 32.8 & 3.55 \\
14 July & 10.7 & 30.4 & 28.5 & 4.58 \\
28 July & 7.6 & 23.8 & 48.2 & 2.23 \\
04 Aug. & 8.1 & 25.3 & 30.1 & 3.55 \\
18 Aug. & 6.6 & 25.2 & 28.8 & 3.60 \\
25 Aug. & 8.7 & 29.4 & 19.7 & 5.00 \\
01 Sep. & 6.3 & 25.7 & 43.0 & 2.94 \\
08 Sep. & 4.9 & 19.0 & 62.9 & 1.74 \\
22 Sep. & 5.6 & 18.3 & 25.0 & 3.06 \\
07 Oct. & 4.4 & 17.6 & 51.3 & 1.89 \\
\hline
\end{tabular}

and $5.00 \mathrm{kPa}$ ). The highest values of relative humidity and lowest VPD (at solar noon) coincided with a period of rainfall in July and September.

At the beginning of the experiment, trees in $\mathrm{T} 1$ were $1.7 \pm 0.1 \mathrm{~m}$ tall and grew to $1.9 \pm 0.1 \mathrm{~m}$ at the end of the experiment. In 2005, budburst occurred on 20 April, bloom on 28 May, pit hardening on 14 July, and veraison on 29 September.

\section{Relative extractable water (REW)}

The seasonal trend of REW in the wetted soil volume to $1-\mathrm{m}$ depth is presented in Fig. 1. Low rainfall during autumn 2004 and winter and spring 2005 (Table 1) did not allow REW to recover to full water-holding capacity. Clear differences in REW evolution were observed among irrigation treatments. T4 fell continuously from 26 May until 29 September. T1 and T2 presented similar REW patterns, maintaining high values until 7 July and then decreasing. This could be due to the fact that $\mathrm{T} 1$ was irrigated to maintain only the upper soil layers $(0.3 \mathrm{~m}$ depth) close to field capacity. After 15 August, less irrigation was applied. In T1 and $\mathrm{T} 2$ the highest REW during the experimental period was reached on 30 June. The pattern in T3 is distinct due to the valve failure. In that treatment, REW rose rapidly and reached the highest value of the experiment 4 days after the failure (0.96). It then fell rapidly and the seasonal trend approached $\mathrm{T} 4$ in the second half of the season. In all treatments the lowest values were achieved on 29 September followed by a slight increase due to an irrigation and rainfall. The lowest experimental value was reached in T4 (0.13). In all treatments, REW was less at the end of the experiment than at the beginning, on 29 September being 26, 32,24 , and $22 \%$ of the value on 2 June for T1, T2, T3, and T4, respectively. The differences in the water applied were not reflected in large differences in REW. Mean seasonal REW of T2, T3 and T4 during the growth and experimental period were 82,94 , and $71 \%$ and 84,90 , and $69 \%$, respectively, of T1. Due to high variability $(\mathrm{CV}=56 \%)$ significant differences $(P<0.10)$ among treatments were established on only 2 occasions. REW in

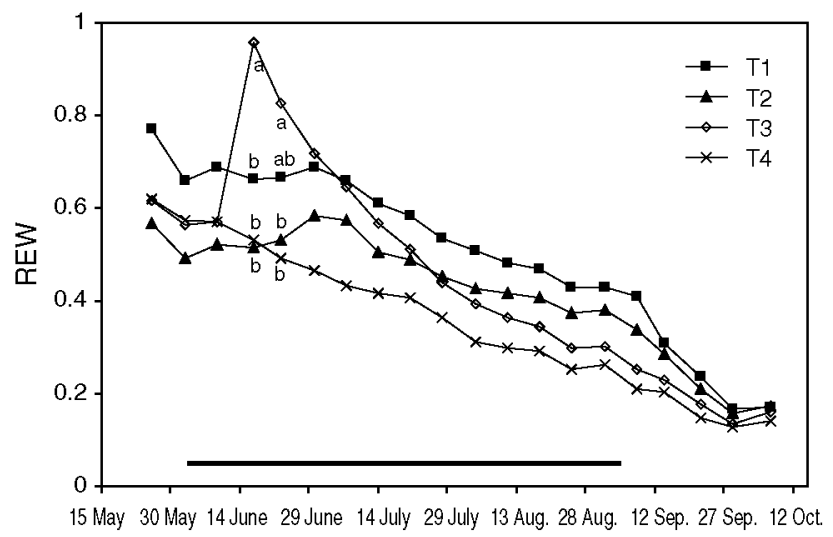

Fig. 1. Relative extractable water (REW) at $1-\mathrm{m}$ depth and $0.30 \mathrm{~m}$ from a drip emitter of various irrigation treatments. $\mathrm{T} 1$ was irrigated to maintain soil close to water-holding capacity; T2, T3, and T4 received 76,72 , and $29 \%$ of water applied to T1. Values are means of 4 repetitions. Treatments with the same letter are not significantly different by Duncan's test at $P<0.10$. Average $\mathrm{CV}=56 \%$. The experimental period is indicated by the line. 
$\mathrm{T} 3$ was significantly higher than in $\mathrm{T} 2$ and $\mathrm{T} 4$ in 17 June and 23 June.

Trees in all treatments obtained water from depth in the rooting zone. At the end of the experiment, $\theta$ at $0.9-$ and $1-\mathrm{m}$ depth was $86 \%$ of that at the outset. No drainage was observed in the treatments, except in $\mathrm{T} 3$ after the valve failed and $\theta$ increased sharply at 0.9 - and 1.0-m depth (data not presented).

\section{Shoot growth}

Shoot length followed a hyperbolic pattern (Fig. 2), reaching plateaux in $\mathrm{T} 1$ and $\mathrm{T} 2$ on $8 / 9$, in T3 on 11 August and in T4 on 21
July. At the end of the experiment (29 September) average shoot length was $18.5,18.8,17.5$, and $8.8 \mathrm{~cm}$ in $\mathrm{T} 1, \mathrm{~T} 2, \mathrm{~T} 3$, and $\mathrm{T} 4$, respectively (Table 3 ). No significant differences in final shoot length were detected among T $1, \mathrm{~T} 2$, and T3. T4 received $29 \%$ of the water applied to $\mathrm{T} 1$ and shoot length was significantly reduced by $52 \%$.

Overall, the timing of shoot growth varied with treatment. In $\mathrm{T} 1$ and T2, shoots grew mainly in May, June, July and August, T3 in May, June, and July, and in T4 only in May and June. Significant differences were observed among irrigation treatments in monthly shoot growth in July, August and September (Table 3). Shoot growth in T4 was significantly

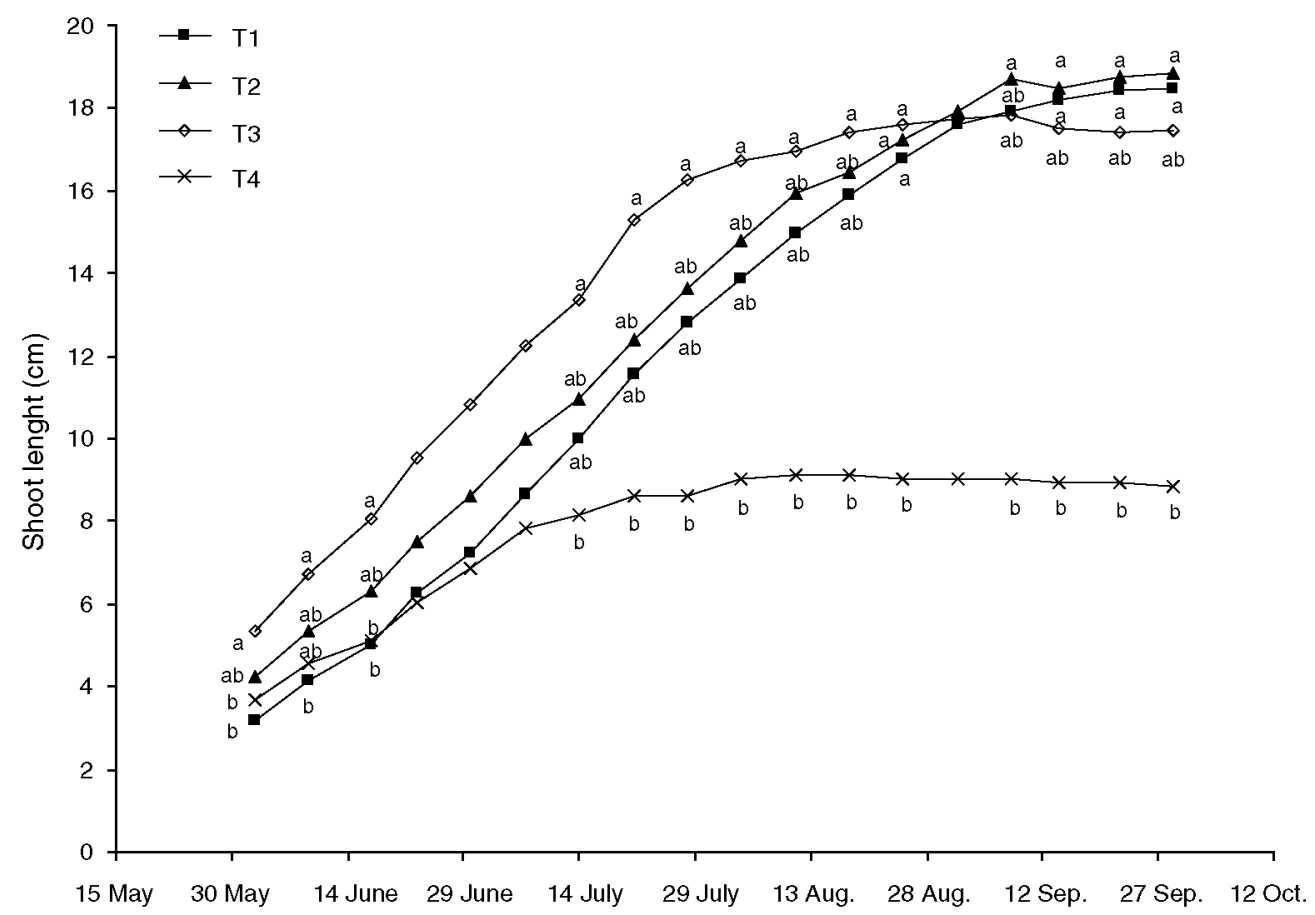

Fig. 2. Shoot length of young olive cv. Cornicabra under various irrigation treatments. T1 was irrigated to maintain soil close to water-holding capacity; T2, T3, and T4 received 76, 72, and 29\% of water applied to $\mathrm{T} 1$. Values are means of 3 observations of 4 repetitions. Treatments with the same letter are not significantly different by Duncan's test at $P<0.05$. Average $\mathrm{CV}=34 \%$.

Table 3. Periodical increase in shoot length and trunk diameter of young olive cv. Cornicabra under various irrigation treatments $\mathrm{T} 1$ was irrigated to maintain soil close to water-holding capacity; T2, T3, and T4 received 76,62 , and $29 \%$ of water applied to T1. Treatments with the same letter are not significantly different by Duncan's test at $P<0.05$. Values are means of 3 observations of each of 4 repetitions

\begin{tabular}{|c|c|c|c|c|c|c|c|}
\hline & Winter-2 June & 2 June-30 June & 30 June-28 July & 28 July-25 Aug. & 25 Aug-22 Sep. & 22 Sep.-6 Oct. & Total \\
\hline \multicolumn{8}{|c|}{ Shoot growth $(\mathrm{cm})$} \\
\hline $\mathrm{T} 1$ & $3.2 \mathrm{~b}$ & 4.1 & $5.6 \mathrm{a}$ & $4.0 \mathrm{a}$ & $1.7 \mathbf{a}$ & & $18.5 \mathrm{a}$ \\
\hline $\mathrm{T} 2$ & $4.3 \mathrm{ab}$ & 4.4 & $5.0 \mathrm{a}$ & $3.6 \mathrm{a}$ & $1.6 \mathrm{a}$ & & $18.8 \mathrm{a}$ \\
\hline $\mathrm{T} 3$ & $5.3 \mathrm{a}$ & 5.5 & $5.4 \mathrm{a}$ & $1.4 \mathrm{~b}$ & $-0.2 b$ & & $17.5 \mathrm{ab}$ \\
\hline $\mathrm{T} 4$ & $3.7 \mathrm{~b}$ & 3.2 & $1.8 \mathrm{~b}$ & $0.4 \mathrm{~b}$ & $-0.2 b$ & & $8.8 \mathrm{~b}$ \\
\hline \multicolumn{8}{|c|}{ Trunk growth (mm) } \\
\hline $\mathrm{T} 1$ & 2.8 & 4.6 & 3.1 & $2.8 \mathrm{a}$ & $2.0 \mathrm{a}$ & 1.0 & $16.3 \mathrm{a}$ \\
\hline $\mathrm{T} 2$ & 3.0 & 5.5 & 2.1 & 2.1a & $1.6 \mathrm{a}$ & 0.8 & $15.1 \mathrm{a}$ \\
\hline $\mathrm{T} 3$ & 3.2 & 5.6 & 3.1 & $2.3 \mathrm{a}$ & $1.7 \mathrm{a}$ & 0.7 & $16.7 \mathrm{a}$ \\
\hline $\mathrm{T} 4$ & 3.2 & 4.2 & 2.6 & $0.4 \mathbf{b}$ & $-0.1 b$ & 0.3 & $10.7 \mathrm{~b}$ \\
\hline
\end{tabular}


less than in T1 and T2. Although shoot growth in T3 was significantly greater than in $\mathrm{T} 4$ in July, no significant differences were observed in August and September, consistent with similarities in REW (Fig. 1).

\section{Trunk growth}

The seasonal trend in trunk diameter growth is presented in Fig. 3. At the beginning of the season (17 March) the mean diameter was $26 \mathrm{~mm}$, while at the end of experiment (6 October) it had reached 43, 41, 44 and $36 \mathrm{~mm}$ in T1, T2, T3 and T4, respectively. From 2 June until 6 October trunks grew 13.5, 12.1, 13.4, and $7.5 \mathrm{~mm}$ in $\mathrm{T} 1, \mathrm{~T} 2, \mathrm{~T} 3$, and T4, respectively (Table 3 ). In $\mathrm{T} 1, \mathrm{~T} 2$, and $\mathrm{T} 3$ diameter increased continuously during the experimental period into October (Table 3). In $\mathrm{T} 4$, by contrast, trunk diameter growth slowed more rapidly and essentially ceased by 28 July. Trunk diameter increased most in all treatments in June, contributing $28,36,34$, and $40 \%$ of total growth for T1, T2, T3, and T4, respectively.

Significant differences were observed in trunk diameter of the irrigation treatments from 23 June. Although T1, T2, and T3 were not significantly different at any time, T4 was significantly smaller than $\mathrm{T} 3$ from the outset and smaller than $\mathrm{T} 1$ and $\mathrm{T} 2$ after 4 August. Over the season, trunk growth in T4 was $56 \%$ of T1 (Table 3).

The vegetative parameters evaluated were both sensitive to water availability but there was no correlation between growth of trunks and shoots in any treatment (analysis not presented). Shoot length was more variable than trunk diameter. The average coefficient of variation $(\mathrm{CV})$ of shoot length was 3 times that of trunk diameter.
Stem water potential $\left(\Psi_{\text {stem }}\right)$

The highest $\Psi_{\text {stem }}$ values were recorded in all treatments in June (Fig. 4). The first measurements (17 June) were made 4 days after the T3 valve failed, and when T3 $\Psi_{\text {stem }}$ had reached the highest value of the experiment $(-1.2 \mathrm{MPa})$, although this was not significantly different from $\mathrm{T} 1$ and $\mathrm{T} 2$. Afterwards $\Psi_{\text {stem }}$ decreased in all treatments until 22 September. $\Psi_{\text {stem }}$ did not, however, return to the high values observed in June. In all treatments $\Psi_{\text {stem }}$ increased on 8 September due to rainfall (9.6 $\mathrm{mm}$ on 1 September) and irrigation on 4 September although no increase in REW was detected on those occasions (Fig. 1). The lowest $\Psi_{\text {stem }}$ value (-3.3 MPa) was recorded on 22/9 in $\mathrm{T} 3$.

$\mathrm{T} 1 \Psi_{\text {stem }}$ was significantly higher than T4 on all occasions with the largest differences at the end of the season (18 September). The mean $\Psi_{\text {stem }}$ of the experimental and growth periods ( 2 June-25 August) were $-1.7,-1.8,-2.0$, and $-2.2 \mathrm{MPa}$, and $-1.6,-1.7,-1.7$, and $-2.0 \mathrm{MPa}$ for $\mathrm{T} 1, \mathrm{~T} 2, \mathrm{~T} 3$, and $\mathrm{T} 4$, respectively. $\mathrm{T} 1$ and $\mathrm{T} 2$ were not significantly different during the growth period. T3 was not significantly different to T1 until 25 August. At the last measurement (7 October) only T3 was significantly lower than $\mathrm{T} 2$ and $\mathrm{T} 4$.

\section{Leaf conductance $\left(g_{l}\right)$}

The small but significant differences in $g_{1}$ that were observed at the first measurement (Fig. 5) reflect differences in water availability at the outset before irrigation treatments were imposed (Fig. 1).

Leaf conductance increased from spring to summer and then decreased (Fig. 5). In all treatments the smallest values were

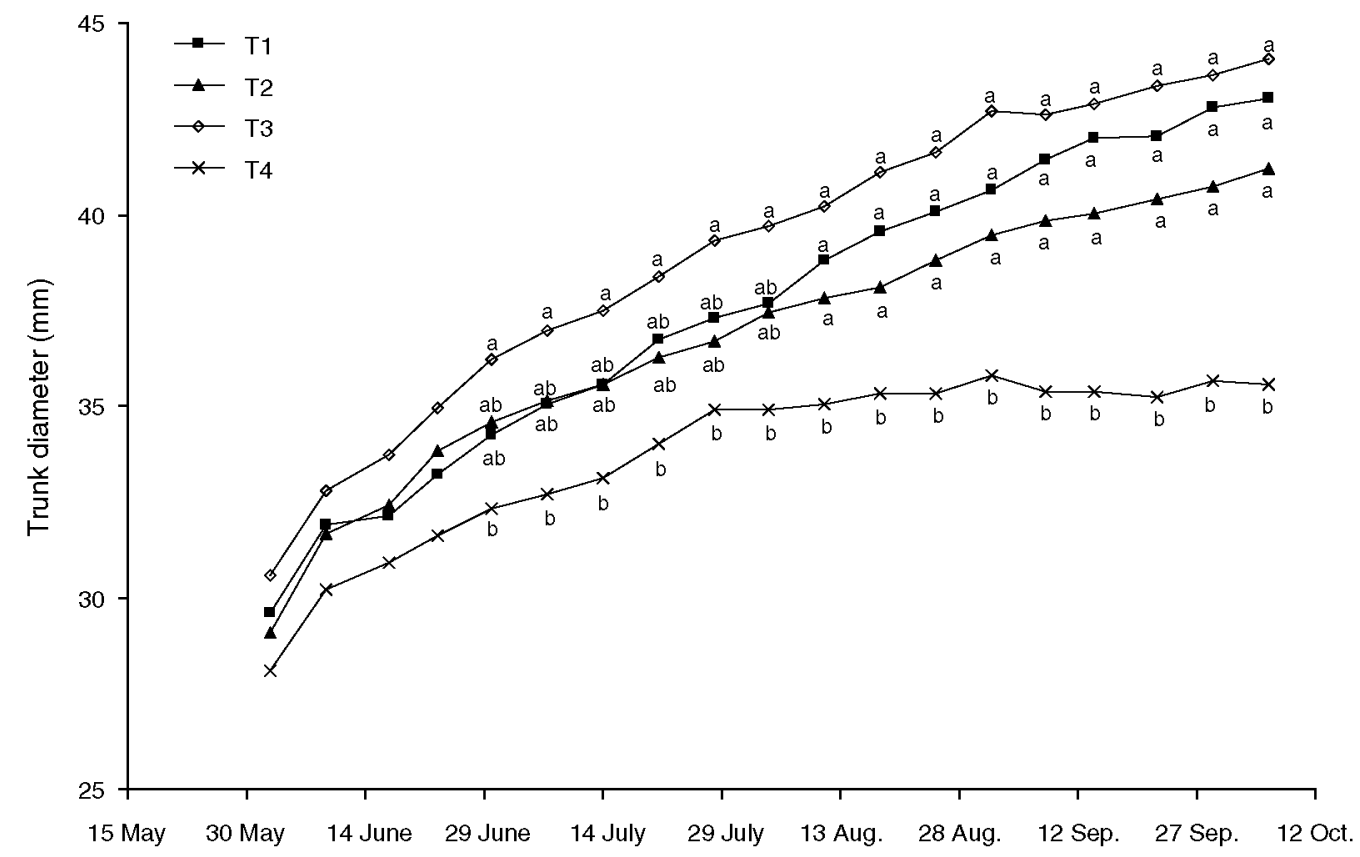

Fig. 3. Trunk diameter of young olive cv. Cornicabra under various irrigation treatments. T1 was irrigated to maintain soil close to water-holding capacity; T2, T3, and T4 received 76, 72, and 29\% of water applied to T1. Values are means of 3 observations of 4 repetitions. Treatments with the same letter are not significantly different by Duncan's test at $P<0.05$. Average $\mathrm{CV}=11 \%$. 


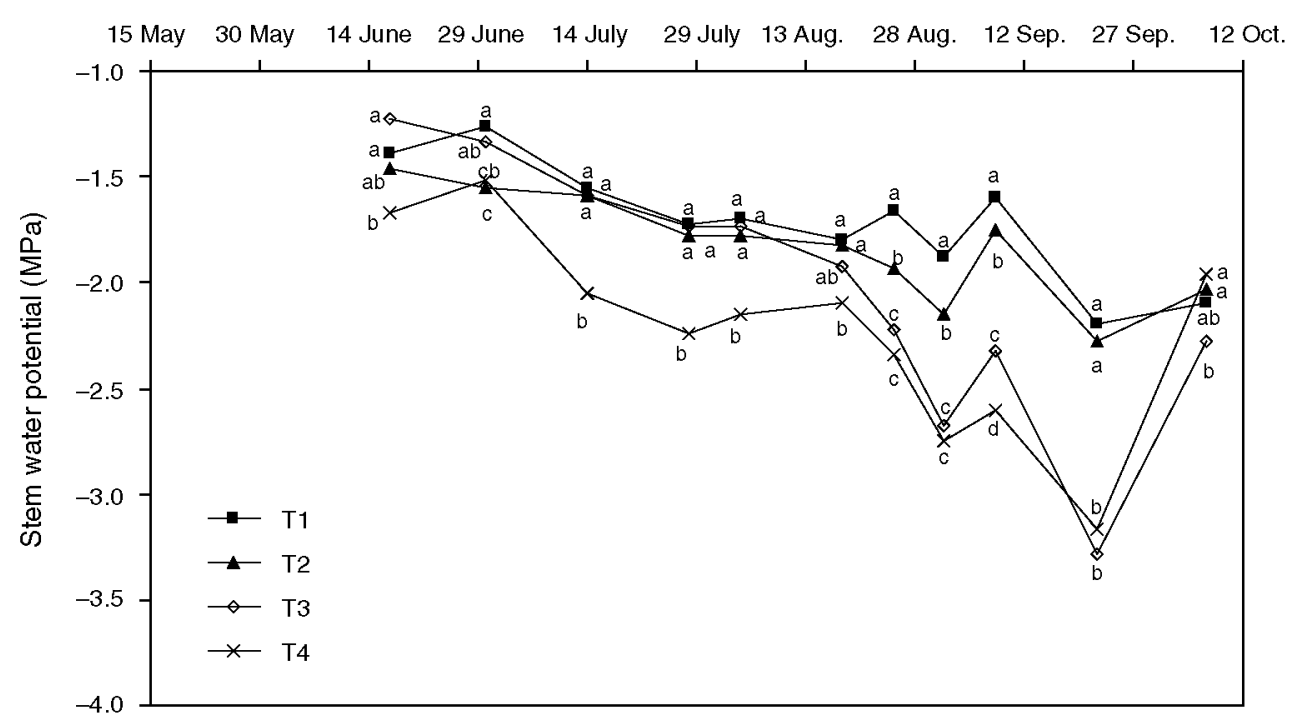

Fig. 4. Stem water potential at solar noon of young olive cv. Cornicabra under various irrigation treatments. T1 was irrigated to maintain soil close to water-holding capacity; T2, T3, and T4 received 76, 72, and $29 \%$ of water applied to T1. Values are means of 4 repetitions. Treatments with the same letter are not significantly different by Duncan's test at $P<0.05$. Average $\mathrm{CV}=7 \%$.

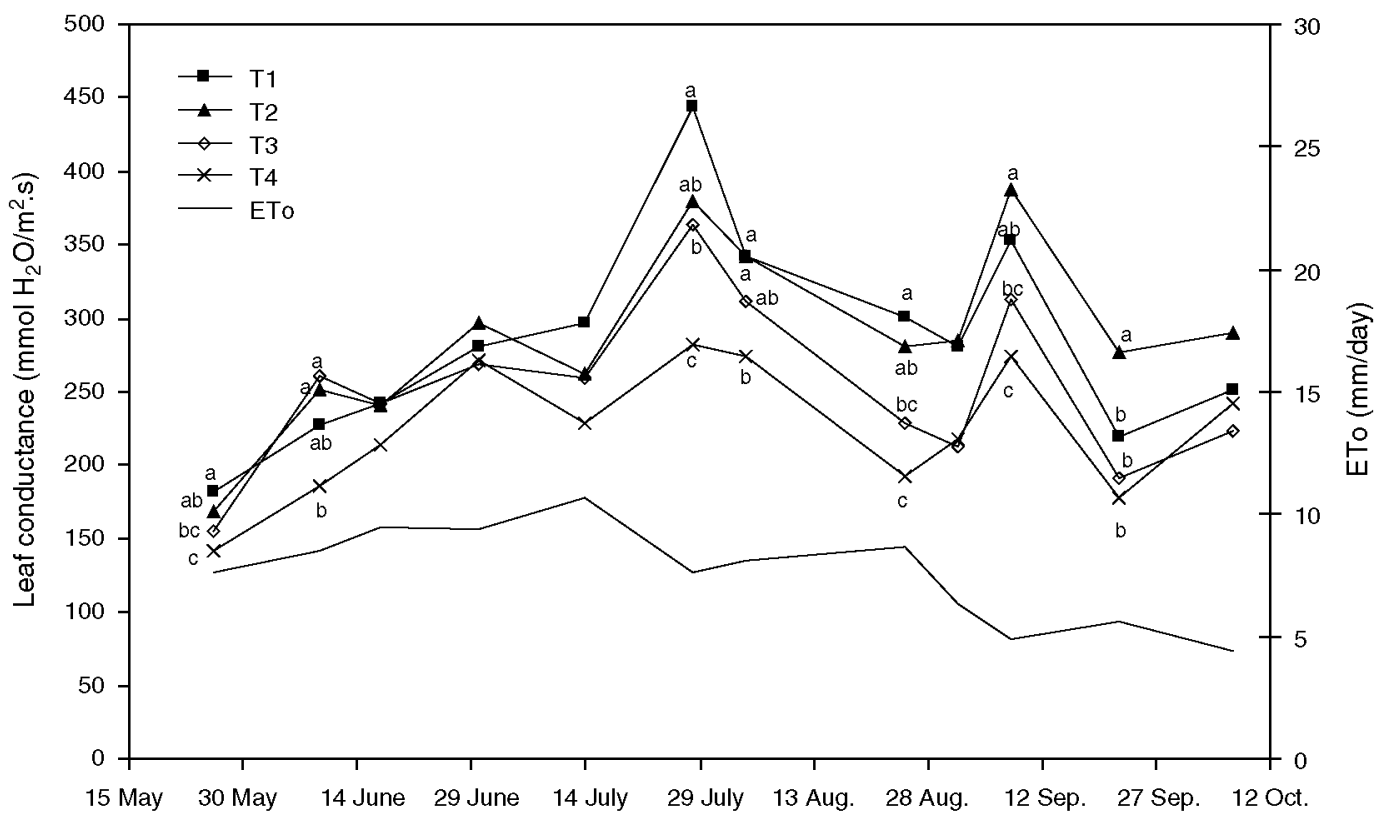

Fig. 5. Leaf conductance at solar noon of young olive cv. Cornicabra under various irrigation treatments and mean daily ETo of the measurement dates. $\mathrm{T} 1$ was irrigated to maintain soil close to water-holding capacity; T2, T3, and T4 received 76, 72, and $29 \%$ of water applied to T1. Values are means of 4 repetitions. Treatments with the same letter are not significantly different by Duncan's test at $P<0.05$. Average $\mathrm{CV}=13 \%$.

measured in 1-year-old leaves at the beginning of the experiment (26May). The highest values of the experiment $\left(443 \mathrm{mmol} / \mathrm{m}^{2} . \mathrm{s}\right)$ were reached in current season's leaves on a cool, humid day ( 28 July) with low VPD ( $2.23 \mathrm{kPa}$ ) (Table 2$)$ by T1 trees. High $\mathrm{g}_{1}$ values were maintained on the low VPD days of September and October. The increase in $\mathrm{g}_{\mathrm{l}}$ observed in all irrigation treatments on 8 September coincided with increased $\Psi_{\text {stem }}$ (Fig. 4) on a day characterised by moderate temperature, high relative humidity and low VPD $(1.74 \mathrm{kPa})$. When T3 reached the highest REW value on 17 June (Fig. 1), g did not exceed that of other treatments.

Mean $\mathrm{g}_{1}$ during the growth period was $290,276,262$, and $232 \mathrm{mmol} / \mathrm{m}^{2}$.s for $\mathrm{T} 1, \mathrm{~T} 2, \mathrm{~T} 3$, and $\mathrm{T} 4$, respectively. Leaf conductance was significantly greater in $\mathrm{T} 1$ than in $\mathrm{T} 4$ at all 
measurements except on 9 June, 17 June, 30 June, and 14 July. Overall, the average value of $\mathrm{g}_{1}$ in $\mathrm{T} 4$ was $88 \%$ of $\mathrm{T} 1$ that maintained similar values to $\mathrm{T} 2$ except on $22 / 9$. After $4 / 8, \mathrm{~g}_{1}$ was not significantly different between $\mathrm{T} 3$ and $\mathrm{T} 4$.

Leaf conductance was shown to be less sensitive to the decrease in soil water than stem water potential and more variable. Significant differences were found among irrigation treatments in $58 \%$ and $100 \%$ of the measurement dates in $\mathrm{g}_{1}$ and $\Psi_{\text {stem }}$, respectively. The average $\mathrm{CV}$ of $\mathrm{g}_{1}$ was nearly double that of $\Psi_{\text {stem. }}$. Leaf conductance was not significantly related to REW (Fig. 6), possibly due to the high influence of the atmospheric demand on $\mathrm{g}_{1}$.

Relationship between vegetative growth, relative extractable water, leaf conductance and stem water potential during the growth period

Fortnightly increments of shoot length and trunk diameter during the shoot growth period (2 June to 25 August) were significantly related to REW at $1-\mathrm{m}$ depth near the wetted soil volume $(0.30 \mathrm{~m}$ from a drip emitter) (Figs 7 and 8). The values corresponding to the T3 valve failure were not included in the regression. The greatest shoot growth was observed in mid July in T3 $(0.22 \mathrm{~cm} /$ day $)$ and the least in T4 $(0 \mathrm{~cm} /$ day $)$ at the beginning of August. The greatest trunk growth was at the beginning of June
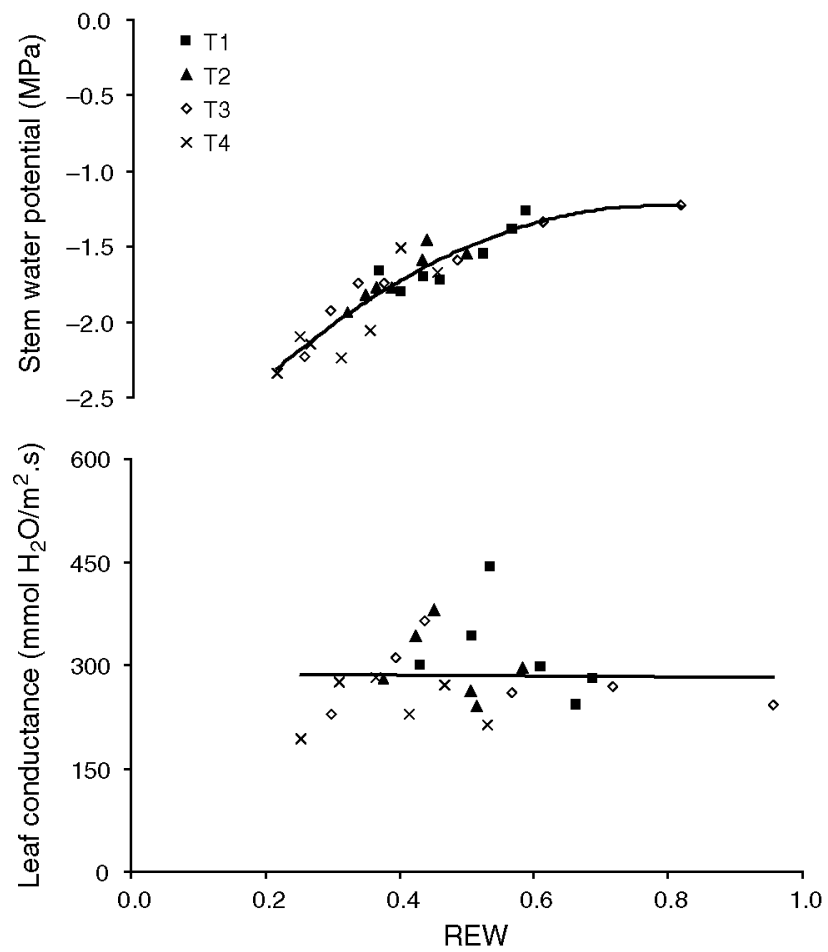

Fig. 6. Relationship between stem water potential and leaf conductance and relative extractable water (REW) at $1-\mathrm{m}$ depth and $0.30 \mathrm{~m}$ from a drip emitter during the shoot growing period (2 June-25 Aug.) of young olive cv. Cornicabra under various irrigation treatments. T1 was irrigated to maintain soil close to water-holding capacity; T2, T3, and T4 received 76, 72 , and $29 \%$ of water applied to T1. Values are means of 4 repetitions. Stem water potential $y=-2.40 x^{2}+4.42 x-3.27, R^{2}=0.86^{* *}$. Leaf conductance $y=-4.79 x+287.56, R^{2}=0.01$ n.s. in $\mathrm{T} 2(0.18 \mathrm{~mm} /$ day $)$ and the least in mid August. Maximum shoot growth was obtained at $0.57-0.72$ REW and the regression reveals that shoot growth is reduced by 33 and $50 \%$ for an REW of 0.53 and 0.45 , respectively.

No significant relationships were observed between shoot or trunk growth and leaf conductance (Figs 7 and 8). Vegetative growth was, however, significantly related to $\Psi_{\text {stem }}$ during the growth period (2 June to 25 August). The relationship to shoot growth $\left(R^{2}=0.71\right)$ was stronger than to trunk growth $\left(R^{2}=0.61\right)$. T3 in August presented less shoot growth for $\Psi_{\text {stem }}$ values
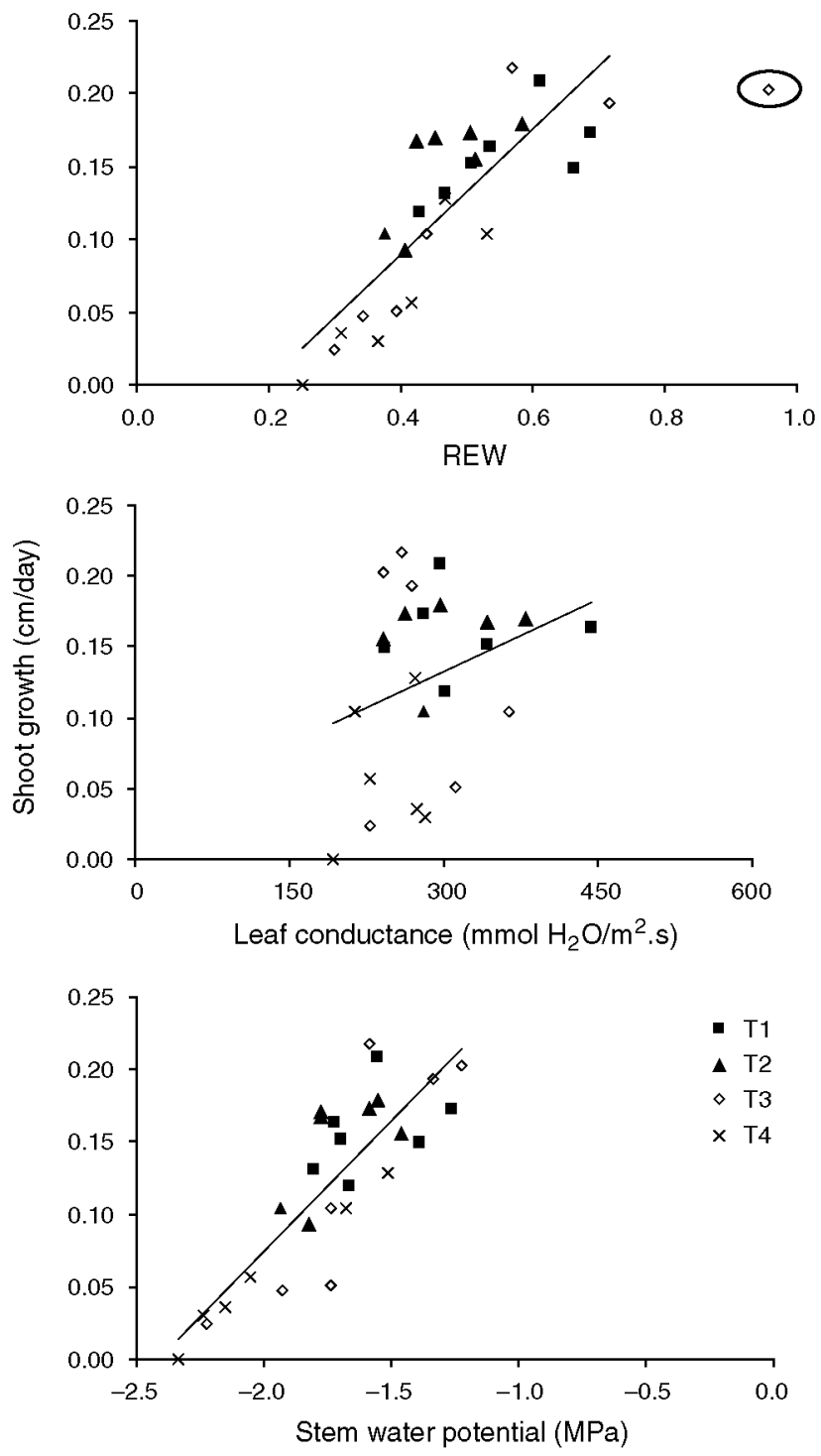

Fig. 7. Relationship between shoot length growth and relative extractable water (REW) at $1-\mathrm{m}$ depth and $0.30 \mathrm{~m}$ from a drip emitter, leaf conductance, and stem water potential during the shoot growing period ( 2 June-25 Aug.) of young olive cv. Cornicabra under various irrigation treatments. T1 was irrigated to maintain soil close to water-holding capacity; T2, T3, and T4 received 76, 72, and $29 \%$ of water applied to T1. Values are means of 4 repetitions. REW $y=0.43 x-0.08, R^{2}=0.70^{* *}$; Leaf conductance $y=0.0003 x+0.03, R^{2}=0.09$ n.s. Stem water potential $y=0.18 x+0.44$, $R^{2}=0.71^{* *}$. The circled point is not included in the regression. 

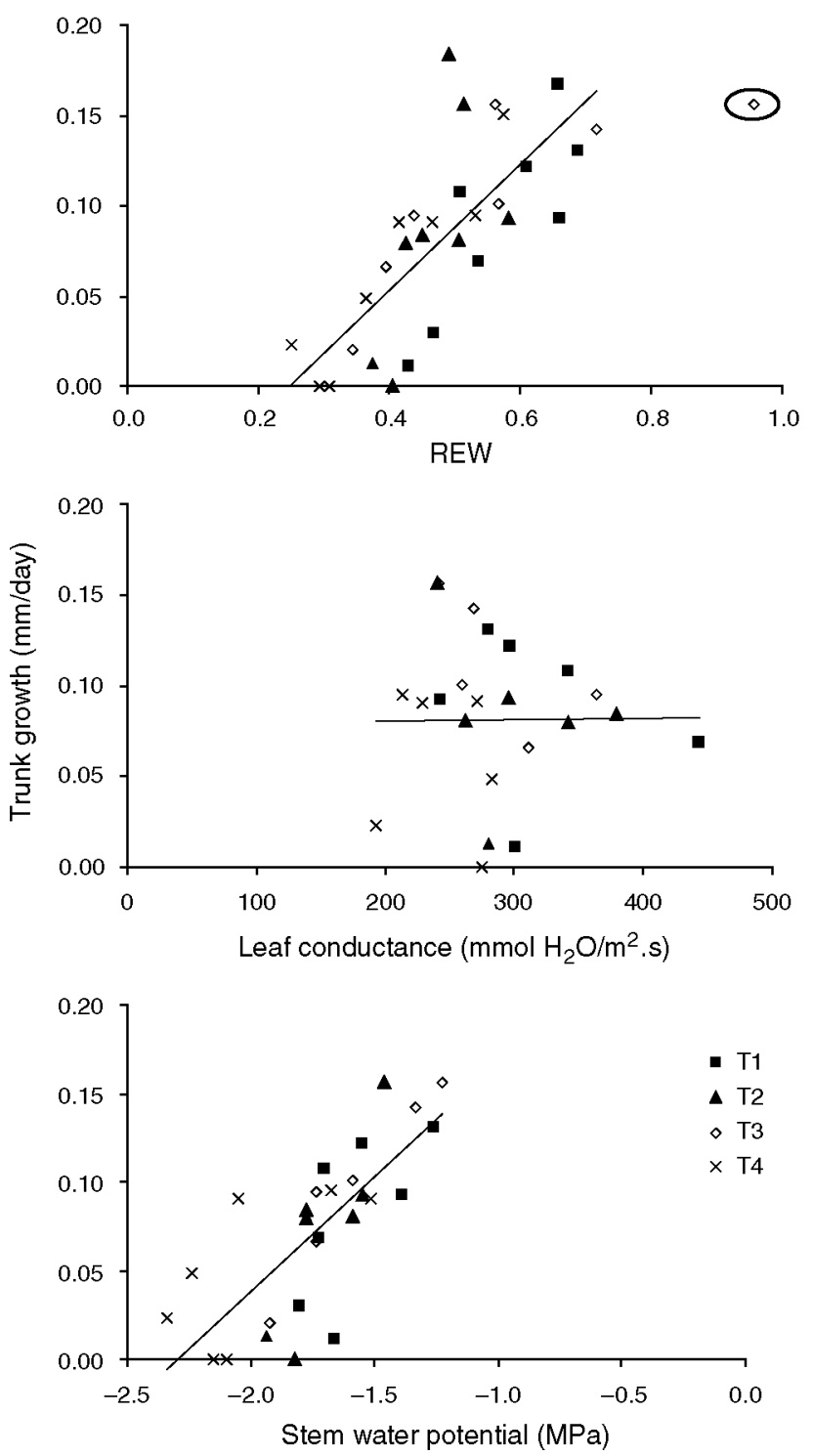

Fig. 8. Relationship between trunk diameter growth and relative extractable water at $1-\mathrm{m}$ depth and $0.30 \mathrm{~m}$ from a drip emitter (REW), leaf conductance, and stem water potential during the shoot growing period (2 June-25 Aug.) of young olive cv. Cornicabra under various irrigation treatments. T1 was irrigated to maintain soil close to water-holding capacity; $\mathrm{T} 2, \mathrm{~T} 3$, and $\mathrm{T} 4$ received 76,72 , and $29 \%$ of water applied to T1. Values are means of 4 repetitions. REW water $y=0.35 x-0.09, R^{2}=0.59^{* *}$; Leaf conductance $y=0.0001 x+0.08, R^{2}=0.01 \mathrm{n}$.s. Stem water potential $y=0.13 x+0.30, R^{2}=0.61^{* *}$. The circled point is not included in the regression.

between -1.74 and $-1.93 \mathrm{MPa}$ compared with the other treatments. In this month, no significant differences in $\Psi_{\text {stem }}$ were observed among T1, T2, and T3 (Fig. 4) but shoot growth was significantly reduced (Table 3 ).

Vegetative growth was greatest with $\Psi_{\text {stem }}$ in the range -1.6 to $-1.2 \mathrm{MPa}$ (Fig. 7). Trunk growth was more sensitive than shoot growth to $\Psi_{\text {stem }}$ and was reduced by 33 and $50 \%$ of the maximum for $\Psi_{\text {stem }}-1.4$ and $-1.6 \mathrm{MPa}$, respectively. The corresponding values for shoot growth were -1.5 and $-1.8 \mathrm{MPa}$.
$\Psi_{\text {stem }}$ was significantly related to REW (Fig. 6) by a curvilinear relationship with a maximum value of $\Psi_{\text {stem }}$ of $-1.2 \mathrm{MPa}$ for $\mathrm{REW}=0.96$ but was not related to evaporative demand (ETo) (analysis not presented).

\section{Discussion}

The irrigation treatments established differences in the pattern of soil water availability $(P<0.10)$ (Fig. 1), tree water status (Fig. 4), leaf conductance (Fig. 5), and significantly affected vegetative growth of young olive trees, evaluated as shoot length and trunk diameter (Figs 2 and 3, Table 3). The response of trunk diameter was less variable than that of shoot length and was highly sensitive to water stress, as previously observed in both young and mature olive trees (Moriana and Fereres 2002; Moriana et al. 2002).

Without water restriction (T1), shoot length (Fig. 2) followed a different trend from that of trunk diameter (Fig. 3). While trunks grew continuously during the entire experimental period, shoot growth stopped at the beginning of September. Vegetative growth did not cease in July and August when a mean maximum temperature around $40^{\circ} \mathrm{C}$ (Table 1 ) may have been expected to restrict photosynthesis, reported in olive to be inhibited at temperatures in excess of $35^{\circ} \mathrm{C}$ (Bongi and Palliotti 1994). The difference in growth pattern between shoot and trunk could arise because trunk growth expresses the vegetative growth of the entire tree (Westwood and Roberts 1970), including sugar accumulation in wood, which occurs at the end of the season, and perhaps responses to thermoperiod and photoperiod, as yet undefined in olive, as autumn approaches.

No significant differences were detected in vegetative growth in T1 relative to T2 even though $24 \%$ more water was applied to T1. Noting that drainage was not detected in T1, this establishes $\mathrm{T} 2$ as the more efficient water management strategy in a young orchard, where maximum shoot growth should be achieved. Irrigation of $81 \mathrm{~mm}$ over the season was able to support maximum vegetative growth under the prevailing environmental conditions (1409 $\mathrm{mm}$ of ETo and $193 \mathrm{~mm}$ of rainfall, Table 1 ). The mean monthly $\mathrm{Kc}$ for the $\mathrm{T} 2$ treatment was 0.086 , being 24 and $64 \%$ smaller than that recommended for olive by Orgaz et al. (2005) and Orgaz and Fereres (2004), respectively. Those authors calculated $\mathrm{Kc}$ for maximum water consumption. Other experiments have also shown that maximum olive growth is achieved with less water than required to support maximum transpiration. Gómez-del-Campo (2007) showed that reducing water application by $20 \%$ from that required to maintain soil at water-holding capacity in 45 -L lysimeters did not reduce total biomass production in young olives and Grattan et al. (2006) reported that maximum shoot growth was achieved in a 3-4-year-old 'Arbequina' hedgerow orchard when irrigation supplied $60 \%$ ETc. In contrast to these treatments, T4 exposed the trees to water stress and modified vegetative development, with shoot and trunk growth ceasing around 21 July and 28 July, respectively. Shoot and trunk growth in T4 during the experimental period were 47 and $56 \%$ of T1, respectively.

The failure of the valve in $\mathrm{T} 3$ prevented the intended treatment sequence but provided interesting data by simulating a wet spring followed by limited irrigation through the remaining season $(49 \mathrm{~mm})$. An almost equal amount of water 
was applied to $\mathrm{T} 3$ as to $\mathrm{T} 2(76 v .81 \mathrm{~mm})$ but the timing was different. Whereas water was applied regularly to $\mathrm{T} 2,36 \%$ of total water was applied to T3 before July. Although final vegetative growth was not significantly different between these two treatments (Table 3), shoot growth stopped in T3 one month before T2. Further, the relationship between $\Psi_{\text {stem }}$ and shoot growth (Fig. 7) revealed that, in August, shoot growth rates in T3 were smaller than in other treatments. At this time, $\Psi_{\text {stem }}$ in $\mathrm{T} 3$ was in the range -1.74 to $-1.93 \mathrm{MPa}$ and not significantly different from $\mathrm{T} 1$ and $\mathrm{T} 2$ (Fig. 4). The cause of this difference in pattern of shoot growth is unknown. Rapid root growth after the valve failed may have later resulted in large root respiration that competed with vegetative growth. Alternatively, a non-hydraulic signal from part of the root system in dry soil could have modified shoot growth (Bongi and Palliotti 1994). Whatever the cause, the result demonstrates that small, regular water application is more efficient in sustaining vegetative growth than large and unequal irrigation at the beginning of the season. To this advantage can be added the reduced risk of disease incidence of Verticilium wilt that is associated with high soil water content (López-Escudero and Blanco-López 2005). The measurements reveal that leaf conductance was a variable parameter (Fig. 5) that showed no relationships with REW

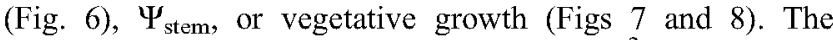
highest value of $\mathrm{g}_{1}$ recorded here $\left(443 \mathrm{mmol} / \mathrm{m}^{2}\right.$.s) was similar to those reported by Moriana et al. (2003) in adult olive trees. The sharp increase in $\mathrm{g}_{1}$ in autumn has also been observed in other experiments (Moriana et al. 2003; Gómez-del-Campo 2007) and gas exchange in olive trees has been reported to be less sensitive to water stress than $\Psi_{\text {stem }}$ (Moriana and Fereres 2002).

There were significant differences in $\Psi_{\text {stem }}$ among irrigation treatments throughout the season, with much less variability that in leaf conductance (Fig. 4). The highest value $(-1.2 \mathrm{MPa})$ that coincided with the highest REW measured in T3 after the valve failed, was lower than reported in experiments on adult trees (Moriana et al. 2003, 2007; Fernández et al.2006) and in an olive hedgerow orchard (Grattan et al. 2006). The low values registered in this work, relative to old trees, could be due to the smaller water storage capacity of wood or lower hydraulic conductance and differences in atmospheric demand on the measurement dates. The possibility that hydraulic characteristics may limit the maximum $\Psi_{\text {stem }}$ of individual orchards is supported by observations here. $\Psi_{\text {stem }}$ decreased progressively, and without difference, in $\mathrm{T} 1$ and $\mathrm{T} 2$ throughout the season even though $\mathrm{T} 1$ received $24 \%$ more water than T2. On 8 September, $\Psi_{\text {stem }}$ increased in response to rainfall and irrigation but no effect was recorded in REW. This suggests that REW responds to partial wetting of the root zone, thus requiring many sensors to define soil water content in the entire root zone if irrigation scheduling is to be based on REW. However, $\Psi_{\text {stem }}$ integrates the water available in the entire root zone. At the end of the experiment $\left(7\right.$ October), $\Psi_{\text {stem }}$ increased markedly in T3 and T4 but only slightly in T1 and $\mathrm{T} 2$. The result was that $\mathrm{T} 1, \mathrm{~T} 2$ and $\mathrm{T} 4$ finished the season with similar values of $\Psi_{\text {stem }}(-2.0 \mathrm{MPa})$ and only slightly greater than T3 ( $-2.3 \mathrm{MPa})$. The question arises, did the small amount of rainfall $(0.4 \mathrm{~mm}$ on 22 September) and irrigation $(7.1 \mathrm{~mm}$ on 29 September) that was sufficient to wet just part of the upper root zone cause this response, even though the effect was barely recorded in REW (Fig. 1), and if so, why was there not a larger response in $\mathrm{T} 1$ and $\mathrm{T} 2$.

The strong relationships observed here with vegetative growth, shoots, and trunks (Figs 7 and 8), establish stem water potential as a good indicator of water stress in olive, as shown previously in other fruit crops (Shackel et al. 1997). Shoot growth was $66 \%$ of maximum at $\Psi_{\text {stem }}-1.5 \mathrm{MPa}$ and $50 \%$ at $-1.8 \mathrm{MPa}$. Although it has been demonstrated that $\Psi_{\text {stem }}$ depends on atmospheric demand (McCutchan and Shackel 1992), in our experiment it was not related to ETo or VPD (data not shown). May be the differences in atmospheric demand between measurement dates were not high enough to determine $\Psi_{\text {stem. Nevertheless a significant curvilinear }}$ relationship between $\Psi_{\text {stem }}$ and REW was found (Fig. 6). A similar relationship was reported by Moriana et al. (2002) over a larger range of values (from -1.0 to $-8.0 \mathrm{MPa}$ ). The requirement of high sensitivity and low variability (Naor et al. 2006 ) is achieved because $\Psi_{\text {stem }}$ effectively integrates the interactions of atmospheric conditions with spatial variability of soil and root distribution.

Finally, although REW was the most variable parameter studied due to the soil and root variability inherent to spaced orchard trees, linear relationships were detected between REW and shoot and trunk growth during the growth period (Figs 7 and 8). This leads to the possibility of automating irrigation provided sufficient samples of soil water status are available. Various authors have reported threshold values of REW of $0.20-0.40$ for their effect on olive water relations (Fernández et al. 1997; Tognetti et al. 2006). In these data, REW in the wetted volume should be greater than 0.45 to ensure that at least $50 \%$ of maximum shoot growth is achieved.

\section{Acknowledgments}

I express my gratitude to Prof. David J. Connor for suggestions on the manuscript, José Ramón Lissarrague for use of the research equipment, and Vicente Gómez for the soil description. I gratefully acknowledge the Instituto Madrileño de Investigación y Desarrollo Rural Agrario y Alimentario (IMIDRA) of the Comunidad de Madrid for access to the olive orchard where this research was conducted. This project was supported by Universidad Politécnica de Madrid and Comunidad de Madrid (Project R05/11243).

\section{References}

Allen RG, Pereira LS, Raes D, Smith M (1998) 'Crop evapotranspiration. Guidelines for computing crop water requirements.' FAO irrigation and drainage paper 56. (FAO: Rome)

Begg JE, Turner NC (1970) Water potential gradients in field tobacco. Plant Physiology 46, 343-346.

Berenguer MJ, Vossen PM, Grattan SR, Connell JH, Polito VS (2006) Tree irrigation levels for optimum chemical and sensory properties of olive oil. Horticultural Science 41, 427-432.

Bongi G, Palliotti A (1994) Olive. In 'Handbook of environmental physiology of fruit crops'. (Ed. BSaPC Andersen) (CRC Press Inc.: Boca Raton, FL)

Connor DJ (2005) Adaptation of olive (Olea europaea L.) to water-limited environments. Australian Journal of Agricultural Research 56, 1181-1189. doi: $10.1071 /$ AR05169

Connor DJ (2006) Towards optimal designs for hedgerow olive orchards. Australian Journal of Agricultural Research 57, 1067-1072. doi: 10.1071/AR05448 
Fernández JE, Diaz-Espejo A, Infante JM, Duran P, Palomo MJ, Chamorro V, Giron IF, Villagarcia L (2006) Water relations and gas exchange in olive trees under regulated deficit irrigation and partial rootzone drying. Plant and Soil 284, 273-291. doi: 10.1007/s11104-006-0045-9

Fernández JE, Moreno F (1999) Water use by the olive tree. Journal of Crop Production 2, 101-162. doi: 10.1300/J144v02n02 05

Fernández JE, Moreno F, Girón IF, Blázquez OM (1997) Stomatal control of water use in olive tree leaves. Plant and Soil 190, 179-192. doi: 10.1023/ A: 1004293026973

Gómez-del-Campo M (2007) Effect of water supply on leaf area development, stomatal activity, transpiration, and dry matter production and distribution in young olive trees. Australian Journal of Agricultural Research 58, 385-391. doi: 10.1071/AR06178

Granier A (1987) Evaluation of transpiration in a Douglas-fir stand by means of sap flow measurements. Tree Physiology 3, 309-320.

Grattan SR, Berenguer MJ, Connell JH, Polito VS, Vossen PM (2006) Olive oil production as influenced by different quantities of applied water. Agricultural Water Management 85, 133-140. doi: 10.1016/ j.agwat.2006.04.001

Hsiao TC (1990) Measurements of plant water status. In 'Irrigation of agricultural crops'. (Eds BA Steward, DR Nielsen) pp. 243-279. (American Society of Agronomy Publishing: Madison, WI)

Jones HG (2004) Irrigation scheduling: advantages and pitfalls of plant-based methods. Journal of Experimental Botany 55, 2427-2436. doi: 10.1093/ $\mathrm{jxb} / \mathrm{erh} 213$

López-Escudero FJ, Blanco-López MA (2005) Effects of drip irrigation on population of Verticillium dahliae in olive orchards. Journal of Phytopathology 153, 238-239. doi: 10.1111/j.1439-0434.2005.00961.x

McCutchan H, Shackel KA (1992) Stem-water potential as a sensitive indicator of water stress in Prune trees (Prunus domestica L. cv. French). Journal of the American Society for Horticultural Science 117, 607-611.

Moriana A, Fereres E (2002) Plant indicators for scheduling irrigation of young olive trees. Irrigation Science 21, 83-90. doi: 10.1007/s00271001-0053-8

Moriana A, Orgaz F, Pastor M, Fereres E (2003) Yield responses of a mature olive orchard to water deficits. Joumal of the American Society for Horticultural Science 128, 425-431.

Moriana A, Perez-Lopez D, Gomez-Rico A, Salvador MD, Olmedilla N, Ribas F, Fregapane G (2007) Irrigation scheduling for traditional, lowdensity olive orchards: water relations and influence on oil characteristics. Agricultural Water Management 87, 171-179. doi: 10.1016/j. agwat.2006.06.017
Moriana A, Villalobos FJ, Fereres E (2002) Stomatal and photosynthetic responses of olive (Olea europaea L.) leaves to water deficits. Plant, Cell \& Environment 25, 395-405. doi: 10.1046/j.00168025.2001.00822.x

Naor A, Gal Y, Peres M (2006) The inherent variability of water stress indicators in apple, nectarine and pear orchards, and the validity of a leafselection procedure for water potential measurements. Irrigation Science 24, 129-135. doi: 10.1007/s00271-005-0016-6

Naor A, Klein I, Hupert H, Grinblat Y, Peres M, Kaufman A (1999) Water stress and crop level interactions in relation to nectarine yield, fruit size distribution and water potentials. Journal of the American Society for Horticultural Science 124, 189-193.

Orgaz F, Fereres E (2004) Riego. In 'El cultivo del olivo'. (Eds D Barranco, R Fernández-Escobar, L Rallo) pp. 323-346. (Mundi-Prensa Publishing: Madrid, Spain)

Orgaz F, Villalobos F, Testi L, Pastor M, Hidalgo JC, Fereres E (2005) Programación de riegos en plantaciones de olivar. Metodología para el cálculo de las necesidades de agua de riego en el olivar regado por goteo. In 'Cultivo del olivo con riego localizado'. (Ed. M Pastor) pp. 83-138. (Mundi-Prensa Publishing: Madrid, Spain)

Pastor M, Castro J, Mariscal MJ, Vega V, Orgaz F, Fereres E, Hidalgo J (1999) Respuestas del olivar tradicional a diferentes estrategias y dosis de agua de riego. Investigación Agraria, Producción y Protección Vegetales 14, 393-404.

Shackel K, Ahmadi H, Biasi W, Buchner R, Goldhamer D, et al. (1997) Plant water status as an index of irrigation need in deciduous fruit trees. HortTechnology 7, 23-29.

Tognetti R, d'Andria R, Lavini A, Morelli G (2006) The effect of deficit irrigation on crop yield and vegetative development of Olea europaea $\mathrm{L}$. (cvs Frantoio and Leccino). European Journal of Agronomy 25, 356-364. doi: 10.1016/j.eja.2006.07.003

Westwood MN, Roberts AN (1970) The relation between cross-sectional area and weight of apple trees. Journal of the American Society for Horticultural Science 95, 28-30. 